\title{
Building of the Gore: \\ extracts from the diary of shipwright Robert \\ Gilkison
}

\section{Walter Lewis, ed.}

Le présent article comprend des passages concernant la construction du bateau à vapeur Gore extraits des journaux intimes de Robert Gilkison, qui a été l'architecte naval de la Niagara Harbour and Dock Company de 1834 à 1840. L'intérêt à l'égard de la construction de ce bateau à vapeur du HautCanada plutôt ordinaire est dû en partie à son caractère tout à fait ordinaire. À cela s'ajoute le fait qu'il existe, au moins en ce qui concerne les Grands Lacs, très peu de sources qui présentent ce niveau de détail sur le rythme de construction des navires.

In 1909, the Niagara Historical Society published extracts from the diaries of shipwright Robert Gilkison, contributed by one of his nieces, Augusta Isabella Grant Gilkison. ${ }^{1}$ The diaries, and other family papers eventually made their way to what is currently called the Library and Archives Canada, in Ottawa where they form the "William Gilkison and family fonds" (R3450-0-9-E, formerly MG24I25).

In selecting the extracts for the six pages of the NHS article, Miss Gilkison included only two references to the Gore: the contract for her construction and two sentences about her launch. The diaries have much, much more to say about the process.

Born in Queenston, Upper Canada, in 1810, Robert left for Scotland with his parents at the age of five. At fourteen he was apprenticed to John Wood, a well-

\footnotetext{
1 Augusta Isabella Grant Gilkison, "Early Ship Building at Niagara," Niagara Historical Society, no. 18 (1909), 29-35.
}

The Northern Mariner / Le marin du nord, XXIX, No. 2 (Summer 2019), 149-58 
known shipbuilder at Port Glasgow on the Clyde. Ten years later, in 1834, he emigrated back to Upper Canada where he was engaged by the Niagara Harbour and Dock Company. Over the next few years he would be responsible for the new construction at the yard, including Traveller (1835), Experiment (1837), Queen Victoria (1838), Gore (1839) and Niagara (1840). In addition, he was largely responsible for the ship repair business on the company's marine railway, especially during the rush at the beginning and end of the shipping season.

Part of the interest in the construction of this otherwise rather ordinary Upper Canadian steamboat is precisely her ordinariness. It is also the case that, at least on the Great Lakes, there are very few sources that offer this level of detail about the rhythm of vessel construction.

\section{8}

June 21: Mr. Lockhart ${ }^{2}$ has succeeded in disposing to "Government" his small steamer the Experiment, for $£ 4,500 .{ }^{3}$ In consequence of this sale, he has determined to replace her with another boat of somewhat larger dimensions, a measure which will give the Co'y employment for nearly the succeeding eight months. I shall therefore have plenty to do and anticipate producing a very different vessel to the "Exp", though she has been throughout a most fortunate craft. Mr. L. says her profits [sic] have been at least $£ 2,000$, excellent, certainly, for $\underline{12}$ months work.

August 3: Bussiness [sic] continues very dull in my profession there is very little prospect of activity this summer. Still I may perhaps be employed should Mr. Lockhart determine to construct another Steamer. On Tuesday we have a meeting of directors, when some measures will be taken to keep the works going.

August 6: ... I require something to stimulate my mind. the present is excessively dull, as no employment offers itself to occupy my attention, but a few days will determine whether the comp'y intend building or not.

August 8: Warm. Rode for an hour this morning, and now think of visiting the woods for the purpose of selecting such a piece of timber as will be suitable for a steamer's keel should the Comp'y propose building. At any rate the information will reward me for the long ride, which is through rather a rough country.

Rode 12 miles but found not what I sought!

2 James Lockhart, then a merchant of Niagara, had been among the original petitioners for the incorporation of the Niagara Harbour and Dock Company, and had commissioned both the Experiment and the Queen Victoria from the Company.

${ }^{3}$ Experiment was part of Captain Sandom's fleet patrolling Lake Ontario in the wake of the Rebellion of 1837 , and was present at the Battle of the Windmill. 
August 9: Today we have a meeting of the Directors, and I anticipate they will effect certain arrangements calculated to enable them to commence building another Steam boat, without further delay. If they should not, it will not be in my power to find work for those hands I have got employed, and moreover, cannot fail to destroy the department under my charge.

August $16^{\text {th. }}$ : Very wet. Still confined to my quarters where, so unsettled does my brain continue, that I find myself incapable of grappling with any study, or pursuing with the slightest pleasure the further extension of my professional knowledge. Indeed, at the present time, there appears a stagnation in the affairs of the Ship Building department at the Dock Establishment. However, a few days will determine, it is said, what are to be the future plans of this Coy. Another Steamer will in all probability be speedily contracted for. Such an arrangement will of course keep me actively employed.

August $18^{\text {th: }}$ Weather continues cool \& agreeable without any news worth noting. Bussiness [sic] is still very dull. In fact I begin to fear we shall not have a vessel to build this year. If so, my department will be annihilated [sic]. However we look forward to brighter prospects.

August 27: Have this moment returned from the "Dock" where I have been engaged in hauling up on the Rail Way the largest schooner on Lake Ontario. ${ }^{4}$ The task, it gives me pleasure to add, we executed admirably, a circumstance highly gratifying to my feelings, as many apprehensions were entertained relative to the successful issue of the undertaking.

A very wet, disagreeable day.

My workmen from the length of time they have been kept without pay, and the irregularity with which it has been doled out, has at length tended to arouse a spirit of insubordination, which will ultimately induce them to desert the place. The consequence of course will be destruction to my department. However, I shall make one effort to obtain a settlement for the men, and point out to the "President" the results, should they not speedily settle with the workmen and obtain some employment for their work. It is a pity to see the establishment going to ruin, especially when one is aware that the whole proceeds from Mismanagement, in fact the Pres \& Secretary are both old soldiers, and not men of business. The affair is above their capacity, and will terminate in ruin unless taken out of their hands, which I trust it will soon be.

August 29: ...Mr. Lockhart talks of building another steamer of 40 horse power, so that my time will again be employed. Indeed this speculation, I consider

\footnotetext{
${ }^{4}$ Then known as the Birmingham, the hull had been originally launched as the steamboat Alciope, and later renamed the United Kingdom. When wrecked some years after this she was known as Frontenac.
} 
to be excellent as this vessel will be enabled to complete with others at a reduction of expense equivalent to fully $£ 4$ a day, which of itself will furnish a hansome [sic] proffitt [sic] at the end of the season. Besides she will eqal [sic] in speed, if not exceed many of the present steamers.

August 30: A delightful morning refreshed by strong northerly breezes. Rode for nearly two hours. The roads and country pleasant. Next week I propose visiting the "woods \& wilds" if the weather continues fine, my trip may be agreeable. If otherwise, oh! Misery! --- my back; my rump.

$1 / 2$ past 9 o'clock. Engaged during the evening in reflections respecting the proper form to be adopted in the model of Mr. Lockhart's new boat. Have some thoughts of altering the curve of the stem. By diminishing the sweep I anticipate obtaining a finer water-line, and thus reducing the friction of the body when propelled though the fluid and destroying, in a great measure, the present wave, which rises at the entrance of the stem and bow when the vessel is set in motion. Before deciding a model shall be made $\&$ from observations on it, my determinations shall be fixed. A fine cool night.

August 31: Devoted the greater part of the day to my draught. It has not much advanced, so far as I could have desired, but tomorrow my labours shall if possible be more steady, and by Monday a model will be constructed sufficiently displaying the form to give Mr. Lockhart a correct idea of what he may expect from the proposed dimensions. May it please.

September 1: ...Drawing all day.

[September 4: new president of the Niagara Harbour \& Dock Company, William Cayley $\left.{ }^{5}\right]$

October 13: ... A meeting of directors took place at the Dock office this forenoon, the result of which has been favourable as far as regard my employment. Mr. Lockhart it appears is determined to build, so that I shall have my hands full this winter in spite of all the unfavourable prognostics hitherto held forth. Mr. Bethune, another steam-boat proprietor is in treaty with the Comp'y for a boat. ${ }^{6}$ If both are engaged the Dock Comp'y will still flourish.

\footnotetext{
${ }^{5}$ William Cayley was a recent immigrant to Upper Canada who in 1838 was admitted to the bar, the same year he became president of the Niagara Harbour and Dock Company. By 1839 he was also a director of the Bank of Upper Canada. He served in two Conservative administrations in the 1840s and 1850s as Inspector General (in general, in charge of government finances).

${ }^{6}$ Donald Bethune would have several steamboats built at the Niagara Harbour and Dock Company in the early 1840s, beginning with America and Princess Royal both of which were launched in 1841 . His failure to make payments on the mortgages to the Dock Company was largely responsible for the company's failure later that decade.
} 
October 21 [reflecting on the previous week] ... Mr. Lockhart having at length determined on the dimensions of his proposed boat I have been occupied preparing the plans, and also arranging work for the few mechanics employed. Next week, if no interruptions occur, our operations will be in a state of cheerful activity, and ere ten days more, pass o'er over heads we will in all probability have the keel laid, and stem raised of this new vessel, which Mr. L. has some idea of christening the "Gore" after the Township as be resident therein he anticipates she will be unanimously supported

October 25: ...My operations at the new steamer have not proved satisfactory in consequence of the dissapointments [sic] experienced with regard to the supply of timber. Procured a stem and anticipate obtaining a keel piece to-morrow. In the meantime my men are busily occupied constructing frames and preparing for the actual laying down of the vessel.

November 13: Laid the keel of our new Steamer this forenoon, and shall now proceed vigorously to place her in frame.

[followed by trip to the Grand River to inspect two American steamboats chartered for government service.]

November 26: ... During the week my time has been fully occupied with the new steamer, and repairing a schooner. The frames of the former vessel are nearly completed and upwards of one half in their places. Should the succeeding week prove favourable I expect to have the whole complete and in ere long, ready for planking. The weather has been cold, but is again milder. Today it snows and appears likely to continue.

December 23: ... My occupations during last week have kept me extremely busy. The steamer Traveller has been here \& provided with a new rudder while a schooner likewise required a similar addition to her stern. These several employments together with the construction of the Steamer have been sufficient to prevent the time from being at all burthensome.

1839

January 6: ...Busy during the week @ the Steamer \&c.

January 11: Mr. Lockhart's Steamer is now in frame \& will remain so for a month to season.

January 27: ... Engaged to make a pencil sketch of Mr. Lockhart's new steamer (Gore). A sad task for me to execute as my talents in that line are very 
limited. Still I shall endeavor to comply, although it be Sunday, as Mr. L. departs tomorrow forenoon for Old Scotia, this sketch will be copied \& for a centre for the cockery. So much for that.

February 20: ... All my men are hard at work on the Steamer. The Gun Boat is finished.

March 3: ... Our Steamer is nearly planked and altogether the work is proceeding satisfactorily.

March 17: ... Last week our work at the steamer has succeeded much to my satisfaction and the next will (should the weather continue fine) in all probability be equally so.

March 30: ... During the last week my men have worked most industriously. The steamer is now nearly caulked $\&$ should the succeeding week prove fine she will be nearly finished.

April 9: ... Very busy at present with the various vessels requiring repairs. These various calls upon my attention all affect in some degree the serenity of my temperament, and consequently are greatly against the complaint, which annoys me. ${ }^{7}$... I shall therefore firmly determine on departing for England whenever this steamer of Lockharts is complete.

April 13: ... Intend launching our new steamer on Saturday next. Hauled up two vessels last week. My time of course has been busy, oh very busy!

April 22: This day, at 1/4 past 2 the Gore, Mr. Lockhart's boat, glided beautifully into the water. At first I was fearful she would have given trouble from the circumstance of her not starting immediately on the blocks being removed. The delay arose principally from the tallow becoming hard and forming a solid cake. Thus the vessel's movement [was] sluggish notwithstanding the descent was quite sufficient to ensure her passing freely from the ways.

Draught of water forward 2 feet 8 with false keel 3 feet 4 in. aft, it is about six inches more. Altogether the Gore's appearance in the water is respectable. At the same time, she is stiff, and if when complete with Engine \&c on board she should prove equally so, I shall then feel happy.

... no accident or the slightest negligence occurred, to affect my character as

\footnotetext{
7 The diaries are full of references to "his complaint" which was a recurring medical condition of uncertain diagnosis, but for which he routinely took pills, "showers" and was occasionally bled. In November 1838 he was laid up for several days while on a trip to Buffalo. He planned to return to Scotland in the fall of 1839 , a trip postponed to the following year, and from which he never returned, dying in Leith in 1845.
} 
an attentive careful builder, a circumstance of much importance.

It seems probable from the disposition of the Co'y \& Mr. L that they will immediately build another boat. If so, \& I am really of so much importance that she cannot be constructed without my presence $\&$ superintendence, then it will of course be my duty to remain \& thus defer my intended trip to England untill [sic] the fall of the year. ... My men keep it up, by a dance, this evening, at which I heartily wish them every enjoyment.

April 23: ... The Steamer I am sorry to say leaks. Yet it is to be hoped her seams by to-morrow will have swelled and all rendered tight again. If otherwise, we shall take her on the Rail Way \& there effectually put a stop to all further annoyances from a similar cause.

May 5: ... During the week, business at the dock has been proceeding satisfactorily. The new boat's boiler and the heavier parts of her engine are in their places, and ere the month terminates, I expect she will be nearly completed.

May 12: ... The Steamer Gore is now decked \&c, her boiler, walking beam $\&$ cylinders \& are in their places. Next week the greater part of the engine will be secured. I therefore anticipate it will be in our power to try the boat before the month terminates.

May 19: ... During last week my labours have been devoted wholly to the forwarding of my employers' interests. We are steadily advancing with Mr. Lockhart's steamer and business is proceeding to the satisfaction of all parties.

May 23: ... The engineers are proceeding rapidly with their work at the Gore and a fortnight more will enable them to have the engine in operation.

May 25: ... Capt. Dick ${ }^{8}$ in relation to the Steam Gore, having stated his "opinion", that the boat was lop-sided created in my mind a strong feeling of anger at this expression, as it reflect upon my character as a Ship Builder. This circumstance induced me to speak rather warmly on the subject to "Dick", who of course persisted in his statement, thus irritating \& disturbing my composure till in the heat of passion I called him a liar. In this, I was wrong, as he was partly right in the observations he made, but in error, to express them, till the vessel has completely finished. Until she is so I consider the capt. is decidedly incorrect in making any observations of such a cast as are at all likely to injure or annoy the builder.

\footnotetext{
${ }^{8}$ Captain Thomas Dick, who over the next twenty years would own or co-own several steamboats, most of which were built at Niagara, none of them by Robert Gilkison.
} 
May 28: ... Steamer nearly ready for a trial, but which will not likely take place before next week. Mean time she improves in appearance. We approach the conclusion. My mind continues at times, anxious \& excited, from the frequent calls that have been made upon its resources lately for estimates \&c preparatory to the construction of a new steamer. ${ }^{9}$

June 2: ... On Tuesday the $4^{\text {th }}$ inst. All things being complete it is proposed that the new boat Gore shall be tried and from the present appearances, the general opinion is that her speed will be proportionate to the power applied. If so, my fondest anticipation with regard to the vessel will be realized.

The Comp'y have now engaged to construct a boat for Mr. John Hamilton \& I have agreed to remain until her frames \& model are complete ...

June 4: A general training of the Militia takes place to-day, \& as the greater part of our workmen will consequently be called to attend, we have determined to give the Gore her first trial during their absence.

... In consequence of some alteration in the machinery, our boat cannot be tried to day.

June 7: On the $5^{\text {th }}$ inst. we gave the new boat Gore a trial. Her speed, however, did not equal our expectations as the machinery proved somewhat stiff in its operation. The steam was also insufficient to obtain more that [sic] 20 revolutions of the engine during the whole of the time we were out, a rate which could not be expected to propel the boat above eight miles an hour. ${ }^{10}$

With regard to her stability, being the point upon which I was most doubtful, she exceeded my expectations. While at the wharf although a little crank, yet when under weigh, the vessel in my opinion was perfectly steady and answered every purpose. Her success on that score is to be attributed in some degree to 9 tons of Ballast which we placed in her hold previous to starting, the great part of which can be gradually removed according to the judgment of the Captain.

Notwithstanding the satisfactory trial of this boat, Mr. Lockhart, her owner announces his determination to the Comp'y not to receive the vessel, stating as his reasons, that the vessel was crank, and totally unfit for any useful purpose. He also says that the dimensions of the vessel are not those he gave to the Comp'y, therefore begs to decline receiving the boat $\&$ being considered as her owner. The above intelligence of course has astonished the President \&c, but, as their cause is a good one, of which there is no lack of proof, Mr. Cayley, has determined that the affair shall be brought to trial. The issue cannot be doubtful, as Mr. Lockhart has

\footnotetext{
${ }^{9}$ This would be the Niagara for the Hon. John Hamilton, then living at Queenston, but shortly afterwards at Kingston. Hamilton was, at the time, the largest steamboat owner on Lake Ontario.

${ }_{10}$ Presumably 20 revolutions per minute, otherwise Gilkison would have reported her drifting!
} 
clearly identified himself the owner by his making the various payments as they fell due \& with regard to his not having given the dimensions on his assertion of their being altered, in that point he is also in error $\&$ can be proved by his never having sent to the Company any statement of the same.

Again Mr. L. has the assurance to say I guaranteed the boats being stiff. In reply, should it be my fate to be placed in the witness box to-morrow, I can conscientiously declare, I never made such an assertion. The nearest approach to his statement made by me was that I thought the vessel's dimensions were sufficient to insure stability, but that the engine was heavy \& the stroke lengthy which caused me to apprehend the boat would be a little tender. The result has been as I anticipated. The boat, if without ballast, would be tender, but, as she now stands, her stability is beyond my expectations.

Respecting the dimensions I can there clearly state that Mr. Lockhart frequently inspected the plan \& model previous to our commencing the actually building \& acquiesced in the proportions \&c of the same. ${ }^{11}$

In no respect it is gratifying to reflect have I committed myself. Lockhart is acting under the influence of passion \& bitter feelings towards the Comp'y in consequence of their refusing to accept his terms of payment for the construction of a new steamer made some time ago, together with their refusing to purchase a schooner which he has now on hand for sale. This is the whole cause of his bitter feeling towards the co'y united with the misrepresentations of "Dick." I regret to witness such unpleasant irruptions especially when I shall be a prominent actor in the affair. Still, as we are in the right, it is to be hoped the injured party will be successful....

Meanwhile I shall finish the Gore and place her in perfect order. Mr. Hamilton is expected early next week, when I shall commence operations with his vessel. At present the men are engaged removing materials to the new yard.

June 23: ... Mr. Lockhart has at length agree to accept the Steam Gore, and I am anxiously hurrying on her completion previous to delivery. On the $18^{\text {th }}$ he again tried the vessel, and was highly gratified to find the boat quite answered our expectations. Her speed is, I should think, fully equal to any of the best boats on the lake, and her stability sufficient to enable her to run without the aid of false sides. Notwithstanding a contrary opinion exists amongst the wise heads of the city.

June 30: ... Work at the Gore going on slowly, yet I trust a fortnight more will bring affairs to a conclusion. The finishing department of these boats is always tedious.

\footnotetext{
11 The final pages of the diary contain memoranda with the dimensions of several vessels including Traveller, Experiment and Queen Victoria. Curiously, the only reference to Gore in this section is Gilkison's estimate of labour on the vessel $(£ 1,355)$ and the estimated cost of the timber $(£ 1,552)$ for a vessel of about 180 tons and 45 horse power.
} 
July 2: ... The Gore was again tried last night $\&$ made the trip from Niagara to Queenston in 39 minutes. Downwards in $27 \mathrm{~min}$. being about the rate of the Transit or rather beyond that vessel's general rate of sailing, a speed which is generally reckoned as highly satisfactory.

July 16: ... Took a trip to Queenston in the new boat Gore for the purpose of trying her without ballast. I am sorry to acknowledge that the experiment was anything but gratifying to my feelings as the vessel proved crank and consequently uncomfortable, quite unfit, without false sides or ballast, to succeed as a passage boat. Now, as Mr. L't does not wish the boat to be ballasted the inference is that she must be increased in breadth to insure the requisite stability. As some difficulties continue to exist respecting the settlement of his affairs with the Comp'y, it is not yet decided whether the owner will determine upon having the job executed here or remove to the vessel to Kingston for that purpose. A few days will terminate this unpleasant affair.

July 18: ... Steamer Gore sailed for Toronto with the intention, I believe, of visiting Kingston to have false sides added by the mechanics of the dock yard in that port. The removal of this boat under these circumstances will of course, create in the estimation of the public an unfavourable opinion of my professional abilities. However the vessel is not an uncreditable piece of work. Her model \& execution are neither such as are likely to bring discredit upon this establishment. The true cause of the Gore's being removed arises from the late disagreement of her owner with the Dock Comp'y together with a spiel of irritated feeling on his part.

Note: Gore went into service between Toronto and Hamilton in mid-August 1839, but by the end of the season she was running across Lake Ontario to Rochester. She remained on that route until 1845 when she was squeezed through the Welland Canal and run on a route through Georgian Bay to the Sault. Her career ended about 1861 after several years as a tug on the Detroit and St. Clair rivers. 